\title{
ATTRACTING TALENT TO FAMILY-OWNED BUSINESSES: THE PERCEPTIONS OF MBA STUDENTS
}

\author{
Lucia Ceja \\ Josep Tàpies
}




\title{
ATTRACTING TALENT TO FAMILY-OWNED BUSINESSES: THE PERCEPTIONS OF MBA STUDENTS
}

\author{
Lucia Ceja ${ }^{1}$ \\ Josep Tàpies ${ }^{2}$
}

\begin{abstract}
This paper examines the perceptions that MBA students hold regarding family-owned businesses compared to non-family firms. The study is based on the assumption that attracting talent is critical not only for continuous competitive advantage, but also for the survival of family-owned businesses. Therefore, family-owned firms should promote themselves as equally attractive as non-family organizations, in terms of employment opportunities. MBA graduates represent a rich pool of talent that can help family-owned firms to prosper across generations. One avenue of inquiry in this regard is to study MBA students and their perceptions. Consequently, studying whether MBA students hold a specific image regarding family-owned businesses is brought to the forefront. With this aim, the authors engaged in an enquiry process, dealing with MBA students' perceptions of the strengths and weaknesses of family-owned firms, compared to non-family businesses. The sample was composed of 213 MBA students from 20 different countries. The results showed that MBA students do indeed hold a particular image regarding family-owned firms. More specifically, some of the findings are that MBA students perceive family-owned firms as having more problems within the ownership than non-family businesses, are not as good as non-family firms in attracting talented managers, have less job rotation, are slower in their internationalization processes, are slower in the implementation of new technologies, have more difficulty in issuing equity and the age of retirement is often higher than in non-family firms. Limitations of the study and future research are also discussed.
\end{abstract}

Keywords: family-owned businesses, non-family firms, MBA students, talent, perceptions.

\footnotetext{
${ }^{1}$ Research Assistant, IESE

${ }^{2}$ Professor of Strategic Management, Chair of Family-Owned Business, IESE
} 


\section{ATTRACTING TALENT TO FAMILY-OWNED BUSINESSES: THE PERCEPTIONS OF MBA STUDENTS}

\section{Introduction}

A critical success factor in today's competitive economy is directly linked to the capacity of an organization to attract, select and retain talent. Attracting talent is critical not only for continuous competitive advantage but also for the survival of a business (Taylor and Collins, 2000; Barney, 1991). In the past decade, talent has become the key differentiator for successful organizations (Bhatnagar, 2007). Therefore, maximizing the acquisition of talent is vital in today's highly competitive environment. Moreover, it has been found that through the acquisition of talent, employee engagement and motivation improves, resulting in enhanced firm performance (Ronn, 2007). In this sense, attracting the 'best' employees is a major priority for every organization. Indeed, talent management is becoming a top priority for organizations around the world. Companies worldwide are turning their focus on how to attract, engage and retain the best employees. Therefore, the management of talent now seems to be one of the key functions that Human Resource Management is playing strategically in organizations (Bhatnagar, 2004). For example, a survey of North American and European executives of midsize companies reported that their "most pressing concern" was "hiring and retaining talent" (McKinsey, 2004). In a nutshell, talent has become the key differentiator for human capital management and for leveraging competitive advantage in today's organizations.

Family-owned businesses are often considered as being at the cutting edge of corporate performance, representation of the owners' interests, job creation, wealth development, return on investment, quality of product and service, customization capability, and speed to market (Astrachan and Carey, 1994; Kleiman, Petty and Martin, 1995; Poza, 1995). Family-owned businesses are also famous for their better quality products, which are often a consequence of having the family name on the merchandise; this makes them potent competitors within all markets (Ward, 1987). Moreover, some of the world greatest companies are family-owned businesses and have managed to overcome numerous challenges, such as wars, economic depressions, natural catastrophes and adverse changes in markets. Nevertheless, family-owned businesses cannot extend and maximize former strengths without attracting and retaining the best talent in the world. In this sense, the implications for recruiting and retaining talented employees are vital for family-owned businesses; as they grow in terms of scope of activity and geographical location, they are in greater need of hiring talented employees, both family 
and non-family (Klein and Bell, 2007). Thus it is important for family-owned firms to be conscious of the image that potential employment candidates have about them, and act taking into consideration these perceptions.

In this sense, building successful family-owned businesses take an immense amount of energy, effort and talent. Achieving long term growth and passing down the business from one generation to the next and continuing to thrive can only be achieved by attracting and retaining exceptional people. MBA graduates represent a rich pool of talent that can help family-owned firms to prosper across generations. Therefore, family-owned businesses should promote themselves as equally attractive as non-family organizations in terms of employment opportunities. One avenue of inquiry in this regard is to study prospective employees, such as MBA students, and their perceptions. Michael-Tsabari, Lavee and Hareli (2008), for example, found that MBA students perceive the family-owned firm to be more emotional and more nepotistic than non family-organizations. The authors also found that, in general, MBA students prefer to choose a job in a non-family firm, indicating that the minority of MBA graduates will end up working for a family-owned business. Similarly, a study by DeMoss (2001) discovered seven myths that, in her opinion, form people's stereotyped view of familyowned firms. The study showed that people often view family firms as having little impact on a country's economy, they are in a continuous battle for survival, the family has a negative impact on firm value, the levels of nepotism are higher than in non-family organizations, they are not good at planning for the future and they have little impact on the society in which they operate. Moreover, the author found that for next generation members, working in their familyowned firms is their second occupational choice.

From these research findings, it seems that family-owned businesses are generally perceived as a unique type of organization, different from other companies. It would be of interest therefore to study further, from the point of view of MBA students, what specific issues differentiate family-owned businesses from non-family firms. The purpose of this research is to gain a better understanding of MBA students' perceptions about family-owned firms, when compared to non-family firms. Why are the perceptions of MBA students about family-owned firms relevant? For three reasons: One is that MBA students are highly talented potential employees who can be a source of competitive advantage for family-owned firms; therefore to know what they think about family-owned organizations may be of great help, to project a better fit between the needs of MBAs and themselves. The second is that the information regarding how MBA students see family-owned firms may be informative for the development of MBA courses and teaching material on family firms. Third, there is limited research focusing on the perceptions of MBA students regarding family-owned businesses, thus research on this topic must be brought to the research agenda.

\section{Research Questions}

The study was explorative in nature. More specifically, the following research questions were assessed:

What are the perceptions of MBA students toward family-owned businesses in comparison to non-family firms, in relation to: a) implementation of strategic changes; b) financial performance; c) talent management; d) financial difficulties for growth; e) managing people; and f) problems within the ownership? 


\section{Theoretical Background}

\section{Implementation of Strategic Changes in Family-owned Businesses}

Within the implementation of strategic changes there are four areas which, in our opinion, are relevant for understanding the differences between family-owned and non-family firms: the use of new technologies, diversification, internationalization and building strategic alliances.

\section{Use of New Technologies}

Regarding the use of new technologies, research has concluded that family firms tend to use standard production technologies, rather than more cutting edge machinery (Gallo and Sveen, 1999). A reason for this may be that family-owned firms tend to seek strategies that are often narrowly focused on a single product, within a single market, following the standard production technologies that have "always" worked.

Moreover, several studies have found that family-owned firms tend to show lower willingness to adopt new information technologies than their non-family peers (Gallo and Sveen, 1999; Ogbonna and Harris, 2005). Likewise, it has been observed that personal perceptions of general managers play an important role in their disposition towards new technologies (Ogbonna and Harris, 2005). Often when top executives in family-owned businesses, especially the founders, advance in age, their level of risk aversion increases up to the point that they generally decrease their eagerness to change or implement new technologies (Ogbonna and Harris, 2005). From the literature, there appear to be important differences between family-owned firms and non-family organizations in relation to the implementation and use of new technologies.

\section{Diversification Decisions in Family-owned Firms}

In terms of diversification, a number of empirical studies have shown that family-owned firms tend to diversify less frequently than non-family firms (Anderson and Reeb, 2003; GómezMejía, Makri and Larraza, 2008) both domestically and internationally (Gómez-Mejía, Makri and Larraza, 2008). Likewise, research on family business has depicted a series of key characteristics of this type of organization, which may led us to expect that family-owned firms differ from non-family firms in their diversification preferences (Denison, Leif, and Ward, 2004; Kets de Vries, 1993). The most well known features are the willingness to maintain family cohesion, which derives from the reciprocal involvement of family members within a common project, as well as the commitment and emotional attachment to the business (e.g., GómezMejía, Makri and Larraza, 2008; Nicholson and Bjornberg, 2008; Thomsen and Pedersen, 2000) and the risk-bearing, stemming from a concentration of the family wealth in a single business (Anderson and Reeb, 2003; Mishra and McConaughy, 1999; James, 1999).

Regarding the first characteristic mentioned above, Gómez-Mejía et al. (2007) proposed that family-owned firms do not diversify as much, because they are reluctant to loss their socioemotional wealth (SEW). SEW is defined as the personal fulfillment that people experience through the unrestricted exercise of personal authority nested in family members; the realization of psychological needs for belonging; identification and intimacy; the perpetuation and exercise of family values; the preservation of a family dynasty; the practicality of placing trusted relatives in important positions; the satisfaction of enhancing a family's social capital; the happiness 
derived from being part of a tight social group and the opportunity to be altruistic (Gomez-Mejia et al., 2007). Most family firms perceive the preservation of this SEW as critical.

Building on the argument above, family firms may be willing to diversify less than non-family firms, as a way to protect their emotional bonds within the family and with the business project. Corporate diversification often requires the entry of external expertise and capital to the firm, thus threatening the power of the family over the firm. In this sense, family businesses are well known for the fact that they are less likely to incorporate outsiders' perspectives and opinions in their decision making.

It is also suggested that family firms may avoid diversification if the firm's specific knowledge of a new business lies beyond the competitive advantage of the family (Stein, 1989). Diversifying beyond the family's area of expertise potentially increases family uncertainty and risk of losing the family wealth, which often results in less diversification. Following this line of thought, a study looking at the longevity of family-owned firms in Spain reported that the oldest family firms in Spain have kept a well-centered position within the market, focusing on specific products for a long time (Fernandez and Tàpies, 2008).

Finally, it is important to note that although we find strong evidence that family-owned firms are associated with less corporate diversification, there are cases in which they are willing to diversify and when they do, the impact of diversification on firm value tends to be more positive for family-owned firms than for non-family firms (Gómez-Mejía, Makri and Larraza, 2008). This might be explained by the fact that family-owned businesses focus more on long term strategies and therefore when they decide to diversify it is because such a strategy will increase their wealth in the long run.

\section{Internationalization in Family-owned Businesses}

Several empirical studies have found remarkable differences in the speed and style with which family-owned businesses proceed in their international ventures. More specifically, research emphasizes that the main characteristics of family-owned firms are the causes of their slowness in their internationalization processes. Some of these features include: the concentration of decision-making power in the hands of a small group of family shareholders, and the prolonged presence of the same people at the head of the organization, which can make the management more rigid (Gallo et al., 2004).

Likewise, Gallo and Estapé (1992) found that family-owned businesses tend to internationalize later and much more slowly than non-family firms. Yet, despite the fact that family-owned businesses appear to internationalize at a slower speed, there have been some studies which found that an important number of family-owned firms that decide to get into the international market make this step once they have reached the end of the first generation (Simon, 1996). Moreover, Davis and Harveston (2000), argue that the level of internationalization of family-owned firms within the first generation is correlated to the age and education of the founder and the degree to which the family firm has invested in new technologies. In this line, Graves and Thomas (2004) highlight that those older and larger family-owned firms who are committed to innovation and networking and have an orientation towards growth are more likely to internationalize in their operations. Likewise, another study by Gallo and García Pont (1996) concluded that the more generations involved in the business, the more the owning family is likely to consider reaching a market position outside their home country. More specifically, the authors observed that multigenerational family-owned firms achieve higher levels of internationalization. 
Research on strategic alliances in family-owned firms has shown that most family-owned firms lack the trust in potential external partners and, therefore, do not pursue alliances with other organizations as much as non-family firms (Gallo et al., 2004). Nevertheless, family-owned firms in which ownership is shared with non-family members or institutions tend to develop the ability to trust other organizations and, when the need to internationalize arises, they often seek strategic alliances with other companies and generally form 50/50 joint ventures (Gallo et al., 2004). Therefore, it seems that strategic alliances can be a vehicle for internationalization, as well as for other processes involving change in the power structure of the business. Familyowned firms are often not used to working with outsiders and therefore can be more reluctant to form alliances. Sharing ownership with outside-family partners appears to be a big challenge for family-owned firms, a challenge that, if it is in line with the family strategy, can be a good opportunity for the family firm to develop the ability to operate in situations where the power lies not only within the family.

\section{Financial Performance and Family-owned Firms}

Research on this area has found that family-owned firms often outperform non-family firms, in their financial results (Saito, 2008). However, some studies have found that after founders retire, the results are mixed. That is, the financial performance of family-owned firms, managed by the founder's descendants, is often inferior to those owned and managed by the founder (Saito, 2008). Building on these findings, Villalonga and Amit (2006), discovered that family management enhances the financial performance of family-owned firms, when the founder serves as the CEO of the company or as its Chairman with a non-family CEO, but destroys value when descendants serve as Chairmen or CEOs. Moreover, founder-CEO businesses with well established control systems are about 25\% more valuable than non-family firms (Villalonga and Amit, 2006). Using ROA (Return On Assets) measures, it has been found that family-owned firms are significantly better performers than non-family firms (Anderson and Reeb, 2003). Likewise, further testing suggests that greater financial performance in family-owned businesses relative to non-family firms is mostly found in those firms in which a family member acts as CEO. One interpretation of these findings may be that family members have an emotional bond with the business, they understand its purpose and its mission, and therefore family CEOs are likely to view themselves as stewards of the family firm. Furthermore, looking at the value of Tobin's $q$, family-owned firms tend to enjoy about a 10\% greater Tobin's $q$ as compared to non-family firms (Anderson and Reeb, 2003), making them better in their financial performance relative to non-family organizations.

\section{Talent Management in Family-owned Firms}

Looking at past research, the talent management in family-owned firms seems to be different when compared to non-family organizations. In our view, there are nine issues relevant to studying such differences: the skills of the management team, the capacity to attract good managers, salary and fringe benefits, access to information, stock options, freedom over decisions, the selection and training of successors, the quality of the board of directors, and representation of the owners' interests. 


\section{Skills of the Management Team}

The skills of the management team appear to be better in family-owned businesses as shown by research on this area (Demsetz and Lehn, 1985). More specifically, it has been shown that the concentration of shares and control management, gives the family an advantageous position for monitoring the management team of the firm. Since the family's welfare is closely tied to firm performance, family members have strong incentives to monitor the management team and push them to be successful at their tasks. Moreover, it has been observed that firms with more active involvement of the owners in the management team tend to perform better (Demsetz and Lehn, 1985). In this sense, in family-owned businesses, where there is the support of responsible shareholders, the management team will likely develop greater skills, resulting in increased efficiency and higher profitability for family-owned organizations.

\section{Capacity to Attract Good Managers}

A critical issue for family-owned firms is their capacity to attract good family and non-family managers. For both non-family firms and family-owned businesses, there should be no difference of view between the shareholders, in that they want the best people covering the key positions within the company. Nevertheless, family-owned firms, differ in the sense that they, in addition, often have secondary agendas like maintaining the family within the management of the firm and to hold a balance between different branches of the family. Furthermore, in non-family businesses the need for recruiting managers is ongoing, while recruitment in family-owned businesses is often guided by the cycle of generations. Indeed, this may be a real limitation, as outside managers often perceive that a number of jobs in top positions will be held by family members, limiting their opportunities for promotion.

Likewise, a particular strength of family-owned firms is their long term horizon, which is based on the willingness to pass down the family legacy to next generations; however the same long time vision often does not fit easily with the planning of management careers, a reason why family-owned firms tend to struggle more than non-family businesses in attracting good managers (James, 1999). Therefore, it is essential that family firms appreciate this situation and seek the best ways to attract talent to the business, carefully appointing the right family and non-family members to managerial positions. To this end, it is vital to demonstrate that the influence of the family will be used to the benefit of the organization and its employees. Also, the family business must show their strong concern for the future of the firm, which can give managers a sense of security and assurance that they will be able to pursue long term professional goals, within a stable business framework. Moreover, family firms must bring out their positive qualities, such as the family values and principles upon which the business strategy is built. These values are the very reason that makes family firms such a rewarding place to work (Ceja, 2008).

\section{Salary and Fringe Benefits in Family-owned Businesses}

As for the salary and fringe benefits, research comparing family-owned firms and non-family organizations has found that family involvement in the firm does indeed have an effect on the compensation policies (Carrasco-Hernández and Sánchez-Marín, 2007). More specifically, employee compensation at all levels, including salary and fringe benefits, is often lower in family-owned managed firms than in non-family businesses (Carrasco-Hernandez and SánchezMarín, 2007). Certainly, family CEOs are paid less and their pay provides less reward for their 
performance than non-family CEOs. These results go against the notion that founding family CEOs use their position to extract extra wealth from the firm through their own salary.

It is important to understand that compensation systems may vary according to the type of firm: a) family-owned and managed firm; b) non-family firm, and c) non-family managed family business (where the CEO is a non-family member). Some studies have related employee pay levels and ownership structure, showing that managers' pay level decreases as their level of ownership increases, concerning the rest of the employees in the organization (Werner, Tosi and Gómez-Mejía, 2005).

In family-owned firms, there are two reasons that support these findings; the first relates to the fact that the CEO is both one of the main shareholders and the managing director of the firm. Thus, CEOs in this dual position often set themselves lower salaries (compared to CEOs in other firms) and decide to spend more money in the firm where it will enhance the shareholder and firm value, thereby increasing his/her main asset (Gómez-Mejía, Nuñez-Nickel and Gutierrez, 2001). Taking into account that organizations usually aim at maintaining salary differentials among employees, the expectation in this case is for a lower pay level among employees.

In non-family firms, where the CEO is not an owner, and the shareholders are atomistic investors, the CEO's decisions are generally directed toward individual profits such as a higher salary (Carrasco-Hernández and Sánchez-Marín, 2007). A common strategy that CEOs in nonfamily firms pursue is to increase the size of the organization, which is likely to have repercussions on his/her salary and the compensation packages for the employees, making the salaries higher in this type of firm.

In non-family managed family businesses, the CEO is not an owner of the business and the ownership is concentrated among a group of family members. In this situation, the CEO's decisions will be monitored by the family and, thus, he or she may have to follow the family interests. It has been found that this type of firm offers their employees similar salaries to those offered by non-family firms.

\section{Access to Information in Family-owned Firms}

A firm's success in today's challenging competitive environment depends largely on its ability to promote open and collaborative exchanges of information among its employees. This exchange of information can foster the reassessment of beliefs, generating greater understanding of the collective view of the company, aiding to outperform the products, services, and processes of rivals. Research in the field of family firms suggests that access to key information is more difficult in family-owned organizations than in non-family businesses, especially for those employees who are not part of the family (Howorth, Westhead, and Wright, 2004). The information flow between family firm owners and management teams can be affected by the complex entanglement of family, ownership and management systems. The ownership system includes three systems: people who are family members, management members or both. Therefore, family-owned businesses often present information asymmetries between the different systems, with family owner managers, who are members of the three systems, having the greatest access to information.

Moreover, many family-owned businesses are extremely dependent on the "know how" of key individuals, especially the founders of the business or people who have been involved in the family-owned firm for many years (Westhead, Cowling and Howorth, 2001). Passing this 
knowledge to individuals who inherit the business is often a challenging and long process; in this sense, succession processes may be jeopardized if access to key information is limited to a few members of the owning family, especially if there are members of the management team who are non-family members and who are involved in the process of passing the baton to the younger generation. In these cases, owner managers should make an effort to share relevant information to reduce the potential problems derived from the loss of key information and competencies.

\section{Stock Options in Family-owned Firms}

Several studies in the area of stock options have shown that, within listed companies, there are no significant differences between family-owned firms and non-family businesses in terms of the provision of stock options (Hirigoyen and Poulain-Rehm, 2000). However, while both types of firms tend to restrict the availability of stock options to their more senior management and top management people, family-owned firms tend to include a smaller proportion of their top and senior management in the population which is eligible for stock options. That is, more than $40 \%$ of top management is eligible for stock options in 67\% of family firms and $86 \%$ in nonfamily businesses. Moreover, family-owned businesses tend to make stock options available to a larger population of their middle management and non-management employees than nonfamily firms. For example, 16\% of quoted family firms offer stock options to more than 40\% of their non management employees as compared to the $11 \%$ offered by non-family firms (Hirigoyen and Poulain-Rehm, 2000).

\section{Freedom over Decisions in Family-owned Firms}

Regarding the freedom over decisions, family-owned businesses often prove to be highly dependent on a single decision-maker; generally the main owner of the family firm (Feltham, Feltham, and Barnett, 2005). A high level of dependence could be positive for family-owned firms as has been suggested by Daily and Dollinger (1992), in that unified ownership can lead to performance advantages. That is, when one or more family members have simultaneous roles (owner-fatherpresident), decision making often becomes centralized. As a consequence, the efficiency and effectiveness of the decision making process may be increased (Tagiuri and Davis 1996), due to the information availability regarding ownership, family and business; thus, the decisions can be made faster and in the best interest of the family and of the firm. Having the goals of the owners, family and managers aligned allows managers to act resolutely, making the family firm a powerful competitor. Nonetheless, strong dependence on one person or a few family members can be also detrimental to family-owned firms, since they often do not delegate decisions to those with greater expertise; in these cases dependence can become threatening for the business. Similarly, it has been found that dependence on a decision-maker is affected by the age of the founder and the size of the business (Feltham, Feltham, and Barnett, 2005). That is, as the owner gets older and approaches retirement, the dependence on him or her decreases. Similarly, when the business becomes larger, the level of dependence on a single decision maker also declines and thus the access to information may be better regulated by professional structures.

\section{Selection and Training of Successors}

One of the most critical events for any organization is the transfer of power and authority from the incumbent to the successor. To choose and train a successor "well" is one of the most important decisions a family-owned firm can make. It will have an effect on the family and the entire business. 
In this sense, rather than being better or worse, the selection and training of successors in family-owned firms and non-family organizations could be considered as being different. The board of directors of non-family firms is free to select successors - from inside or outside their organizations - who have demonstrated records of achievements and can step immediately into the CEO position, as soon as the incumbent steps out. Moreover, executive successors in nonfamily organizations tend to be externally oriented and detached from the business. In this sense, non-family firms will tend to train their successors through educational institutions, instead of direct interactions such as mentoring and coaching (Fiegener et al., 1996).

In family-owned businesses, the idea of keeping the business within the family is very strong (Ward, 1991), so the board of directors tends to look for successors within the family, although where there are no family members available for the position, they often invite an outsider. In this sense, when a family member is chosen as the successor, there is no guarantee that he or she will possess the talent and experience required to handle a CEO position; thus, family firms tend to place more emphasis on successor training than selection. More specifically, the training of family firm successors often emphasizes tutoring and mentoring in specific skills or knowledge areas, taking a more personal relationship approach that generally involves a strong relationship between incumbent and the successor and other stakeholders. Building on this line, Fiegener et al., (1996) confirmed that family firm CEOs are able to transmit the strategic vision and mission of the business through close incumbent/successor relationships, such as mentoring for long periods of time. In contrast, CEOs in non-family firms have less opportunity to build close incumbent/successor relationships of the same depth. The close relationship between successor and incumbent in family-owned firms is often an advantage over nonfamily firms, as successors' training develops through a lifetime of learning experiences inside the business, which will not occur within non-family organizations.

\section{Quality of the Board of Directors}

Even though the general objective of the board in both types of organizations is the same - looking after the stability and the continuity of an organization - the influence of the family system, on the function of boards of directors, makes a difference in the way an organization is governed. This difference derives from the overlapping roles that stakeholders in a familyowned firm can have. That is, family members working in a family-owned firm can have three simultaneous roles: as family members, as owners and as managers (Tagiuri and Davis, 1996).

An important feature of the family business government system is that boards of directors are dominated by members of the owning family. Often, family-owned firms are reluctant to accept outside directors in the board as the family control over decisions may be threatened. Thus, in family firms, there is a special relationship based on "trust" between the boards of directors, shareholders and the CEO, which creates a virtuous governance circle of trust. In contrast, the relationships among the three groups in non-family firms are based on more detached connections, which often result in an increase in the differences of interests between the three groups. In other words, non-family firm stakeholders tend to seek personal benefit over organizational welfare.

It has been shown that relatives who work together share a sense of identity which often results in significant emotional attachment of the family members towards the business, and this can satisfy their need for security, belonging and social contribution (Lansberg, 1999). Thus board members in family-owned firms are likely to exhibit especially marked levels of stewardship, which helps to align the goals of the family, management and ownership. This way, the 
members of the board of directors can act decisively, as they possess a clear and aligned vision of the firm's mission, principles and values, giving the company a peculiar strength.

\section{Representation of the Owners' Interests}

Based on the agency theory, a common problem in organizations is that managers often have incentives to pursue their own interests, at the expense of shareholders (Allouche and Amann, 1997). In family-owned firms, this problem is often mitigated as there is an overlap of family, ownership and management memberships. Indeed, one of the hallmarks of family firms, which can be a source of advantages and disadvantages (Tagiuri and Davis, 1996), is that the ownership and control systems are combined. In this sense, the interests of the owners are well blended with those of the management team.

It has been suggested that one of the reasons why family firms dominate as a form of business organization is because owners and managers are aligned along the same long horizon and, therefore, they are more capable of overcoming many difficulties faced by companies in which ownership and control are separated (James, 1999). Likewise, it has been asserted that firm value is reduced when ownership and control are separated rather than combined (Jensen and Meckling, 1976). The costs are related to the difficulty of developing contracts, designed to completely and accurately specify the particular actions that managers must perform in the interest of firm owners.

\section{Financial Difficulties for Growth}

\section{Difficulties Obtaining Loans}

Family firms are known for their lower ratio of debt, as compared to non-family firms. Actually, family firms have the same difficulty in obtaining loans as non-family firms. What differentiates them is the unique financial strategy of family-owned businesses, which rests upon the idea of avoiding external debt and using internal financial resources instead.

Villalonga and Amit (2006) found that family firms have significantly lower leverage than nonfamily companies. Likewise, Anderson and Reeb (2003) established that the level of debt in family firms is generally lower than in non-family businesses. We argue that family members represent a unique type of shareholders that posses a special motivation to act as stewards of the family firm, nurturing and grooming it, so subsequent generations can receive it and continue the family legacy. In this sense, family shareholders will tend to be debt averse, as high levels of debt can put the family business at risk.

\section{Difficulties Issuing Equity}

The majority of companies across the world are family-owned businesses, and much of the world's overall employment is provided by family firms. Some authors estimate that as much as $90 \%$ of all companies in developing countries can be classified as family-owned businesses (Dyer, 2003). Most family firms, however, are located at the lower end of the scale in terms of size. A study by Pagano et al. (1998) confirmed that a company's size significantly affects the probability of going public for previously private companies; moreover the authors found that there are few small companies that go public in order to finance their expansion. Therefore, since a large number of family-owned firms do not have the sufficient size to go public, their 
difficulties for reaching the stock market increase. Nevertheless, if we concentrate on the large family-owned business groups, the picture changes and we find that listed family-owned firms often outperform their non-family firm rivals in all sectors (Thompson Financial, 2004). However, large family-owned firms have, in general, lower average share capital and tend not to sell equity to financial institutions or stock market investors who are not family members (Gallo et al., 2004).

As Tàpies and Reinoso (2005) state, there are three main reasons why family-owned firms may struggle to sell equity to outside investors. One reason is the privacy loss that derives from going public. When going public, sudden changes come to the forefront of a family-owned business, for example, the financial situation and the identity of its shareholders become accessible; likewise, the discretion that most family-owned firms enjoy is reduced. Moreover, the salaries and compensations of the family members become public.

The second reason lies within the family fear of losing control and ownership power. In familyowned firms, the financial decisions are strongly influenced by the family and they are associated with the need for control and autonomy. This can explain why family-owned businesses often prefer to meet their financial needs by using internal funding.

The third reason is related to the changes in the performance of the business. The performance of listed companies is judged by external shareholders, and the top management is questioned regarding the dividend policy, the share value and the salaries of top managers, including the CEO. In addition, external shareholders will seek to increase the dividend earnings, year after year, generating pressure to achieve short term results, which may hamper the long term goals of family-owned firms.

\section{Difficulties Including New Shareholders}

Empirical evidence shows that family-owned businesses do indeed have a significantly lower proportion of independent shareholders (non-family members) than do non-family businesses (Villalonga and Amit, 2006). A study by Blondel et al. (2001), researched 250 of the largest publicly traded companies in France. The study confirmed that, within this group of listed companies, where outside shareholders would be expected to be part of the shareholder structure, companies where families are identified as the major shareholders form the majority. Moreover, Poutziouris (2001) emphasizes that family-owned businesses finance their capital necessities firstly by using their available internal funds and then by debt; only as a last resort will they look for external shareholders.

However, it is important to emphasize that, more than having difficulties for accepting new shareholders, family firms are often unwilling to accept outsiders into the "family group", as a consequence of their desire to maintain a close ownership strategy.

\section{Difficulties Retaining Earnings Due to Dividend Policy}

Empirical evidence suggests that family-owned firms have significantly lower dividend rates than non-family firms (Villalonga and Amit, 2006). Likewise, Gallo et al. (2004) confirm that family-owned firms often do not regularly pay dividends. Therefore, family-owned firms seem to differ in their dividend strategies when compared to non-family firms, in the sense that shareholders often receive fewer dividends. 


\section{Managing People}

\section{Job Rotation}

Among family-owned firms, there is a powerful recognition that employees represent an invaluable competitive advantage that must be nurtured and preserved, in order for the business to be successful and long-lived. In this way, empirical evidence suggests that familyowned firms tend to look after the well-being of their employees more than non-family firms (Le Breton-Miller and Miller, 2006).

Family-owned firms also enjoy lower rates of job rotation than non-family firms (Allouche and Amann, 1997; Miller and Le Breton-Miller, 2003). The lower rate of job rotation represents significant cost savings for the company, but more important, it allows employees to stay in the same firm for longer periods of time, letting them absorb the culture of the company, become more familiar with their co-workers and accumulate more knowledge regarding the company and their specific role in the organization. The result is that knowledge is preserved within the business and, therefore, people have the sufficient skills to perform their jobs efficiently. Furthermore, a lower rate of job rotation represents a sense of security and control for employees, which results in people's willingness to take on new challenges and greater autonomy in their jobs.

Likewise, empirical evidence suggests that family-owned firms are less likely to downsize when compared to non-family businesses (Stavrou, Kassinis, and Filotheou, 2006). Family companies also tend to maintain stable levels of employment and avoid firing employees, even during economic crises (Lee, 2006). From these findings, we can infer that family-owned firms tend to follow the intrinsic stakeholder commitment model, proposed by Berman et al. (1999) in which firms are regarded as having a moral commitment to treating stakeholders in a positive way, and this commitment is in turn shaping their strategy and having an impact on their performance.

Likewise, bullying at work, which includes harassing, offending, socially excluding someone or negatively affecting someone's work tasks (Einarsen et al., 2003), is less frequent in familyowned firms than in non-family businesses (Zapf et al., 2003). One explanation of these findings lies within the genuine interest of family-owned firms to create a positive work atmosphere that can retain employees at their jobs for long periods of time.

In this sense, family-owned firms often shape their strategy around a set of family principles and values, which emphasize continuity, integrity and trust among stakeholders. This way, the well-being of stakeholders has an intrinsic value and forms a moral foundation for corporate strategy. Their reluctance to downsize may come from their intention to apply and transmit their values and principles into the community and to subsequent generations. We argue that family-owned firms generally exhibit a sincere interest in stakeholder well-being. Such sincere interest has a positive effect on employees, represented by less job rotation and higher employee commitment.

\section{Age of Retirement}

Family-owned business CEOs stay in their position an average of three to five times as long as CEOs in non-family firms (Lansberg, 1999; Ward, 2004). Miller and Le Breton-Miller (2005) pointed out that, in family-owned firms, CEOs stay at their positions a mean of 15 to 20 more years than CEOs in non-family firms. This is because the ownership status of family CEOs gives 
them the power to remain at their job position for as long as they want. Moreover, as the CEO tenure often depends on the next generation entering the business and covering the managerial positions, they spend longer periods of time in their position. These findings suggest that family-owned firms tend to have very long tenures and thus are concerned not so much with short term results as profits in the long run. In non-family firms, CEO tenures last for about four to eight years (Khurana, 2003). Thus the pressure on the CEO to obtain immediate results is immense, and long term strategies that can be advantageous for the next CEO will more likely be avoided and replaced by short term focused actions, which can produce quick results.

\section{Nepotism}

The term nepotism refers to the favoritism shown for relatives based upon family or friendship bonds (Padgett and Morris, 2005). The practice of nepotism has been conceived as an undesirable attitude by most people (Padgett and Morris, 2005). In order to remain a "family business" these firms often need to hire family members to occupy managerial positions. Moreover, the blood bonds that exist between family members often lead them to act in favor of those who are part of the kinship. Thus, family-owned businesses appear to be highly vulnerable to nepotistic practices. Nonetheless, favoritism also occurs within non-family organizations. A study by Lowery, Petty, and Thompson (2008) showed that a considerable number of employees from several companies in the United States remarked that bonus payments were distributed on the basis of favoritism, such as whether they were friends with their supervisor or whether their supervisor liked them.

Empirical findings show that the practice of nepotism or favoritism in organizations has negative consequences for employees (Padgett and Morris, 2005); that is, when people acknowledge that their supervisor has been hired due to a family connection, they see them as less competent, they have less confidence in these supervisors and provide less support to them (Padgett and Morris, 2005). Moreover, the perception of nepotism may result in lower employee commitment to the business (Padgett and Morris, 2005). Given all these negative consequences, all organizations, and especially family-owned firms, should ensure that the practices of nepotism are well controlled. In this sense, there are myriad ways to ensure that family members and non-family employees can both thrive and have a healthy coexistence in a family firm. To achieve this, family-owned businesses should hire employees based on their skills and strengths, as well as the requirements of the job. Family firms should ask themselves what qualifications are required by the job position; what type of person should be hired? Are there any family members whose skills fit the job position?

\section{Problems Within the Ownership}

There is much empirical evidence that family conflict is a prominent characteristic of familyowned firms (Sorenson, 1999; Eddleston and Kellermanns, 2007). Authors have gone on to say that family firms are "fertile fields for conflict" (Harvey and Evans, 1994, p. 331). Familyowned firms are more often exposed than non-family firms (Schulze, Lubatkin, and Dino, 2003) to relational challenges such as sibling rivalries for gaining their parents affection, children's desire to differentiate themselves from their parents, marital confrontation and self identity conflict, to name a few. Likewise, there is a wealth of research suggesting that relationship conflict, referring to conflict that involves negative emotions like anger, sorrow, worry and resentment, is an intrinsic characteristic of family-owned firms (Johnson and Ford, 2000). Moreover, relationship conflict has been associated with poor performance in family firms 
(Dyer, 1986; Gersick et al., 1997). Accordingly, researchers argue that managing relationship conflict is very important for the survival and success of family firms (Ward, 1987; Dyer, 1986). From the literature, it may be assumed that personal problems within the ownership affect the business more often in family-owned businesses than in non-family organizations. Familyowned firms, therefore, must take a look at their conflict management strategies, i.e., how differences among family members can be best handled and resolved.

\section{Methodology}

\section{a) Instrument}

In order to define a family business we have used the definition agreed by both the Family Business Network (FBN) and the European group of Owned Managed and Family Enterprises (GEEF). A company is considered as a family business if:

1. The majority of votes are in possession of the natural person(s) who established the firm, in possession of the natural person(s) who has/have acquired the share capital of the firm, or in the possession of their spouses, parents, child or children's direct heirs.

2. The majority of votes may be indirect or direct.

3. At least one representative of the family or kin is involved in the management or administration of the firm.

4. Listed companies meet the definition of family enterprise if the person who established or acquired the firm (share capital) or their families or descendants possess 25 per cent of the right to vote mandated by their share capital.

A research questionnaire was developed specifically for this study (see Appendix E). The questionnaire was based on a review of the family business literature looking at the several issues that differentiate family-owned firms from non-family firms. The questionnaire covers six different areas: Implementation of strategic changes, financial performance, talent management, financial difficulties for growing, managing people and problems within the ownership. Participants were asked to respond based on their perceptions of family-owned firms and non-family firms in general.

\section{b) Data Collection}

The questionnaire was pre-tested on ten randomly selected MBA students, to ensure the clarity of instructions and questions asked. As a result of the pre-test, the researchers refined the instructions and improved or deleted unclear questions. The final version of the questionnaire contained 23 items focusing on various aspects of family firms (see Appendix E). Study participants were given standardized instructions for filling out the questionnaire. As in the preliminary study, study participants were asked to respond to questionnaire items according to their perceptions of family firms as compared to non-family firms in general. More specifically, participants were asked to rate each of the statements presented to them, in a Likert scale with six, five and three response options, appropriate for each case. Moreover, the first part of the 
questionnaire was composed of questions related to the demographic characteristics of participants. The questionnaire took approximately 10 minutes to complete.

\section{c) Sample}

Respondents were 213 graduate students, enrolled in a two year Master of Business Administration program. There were 171 males and 42 females. The average age of respondents was 29 years $($ s.d. $=2,02)$. Most participants were from Spain $(60 \%)$, although there were also participants from United States, Portugal, Chile, Mexico, Brazil, Colombia, Germany, India, Russia, Italy, Canada, Greece, China, Japan, Taiwan, Ukraine, Venezuela, Croatia and Bulgaria. One hundred and nineteen participants considered they had a moderate knowledge regarding family-owned business, thirty seven perceived their knowledge about family-owned firms as high, while fifty seven described their knowledge as low. Seventy seven participants had developed their knowledge about family-owned firms from being members of a family-owned business, fifty individuals gained their knowledge through their working experiences in familyowned organizations, seventy two participants stated that they knew about family-owned firms from books, and fourteen participants mentioned that their knowledge about family-owned firms came from other sources. Finally, eighty six MBA students were future family business owners (next generation members) while a hundred and twenty seven were non-family owners.

\section{Results}

Several interesting findings can be drawn from an inspection of the descriptive statistics (see Tables 1.1-1.6 Appendix A). In this section we will summarize the more noteworthy results. Firstly, descriptive statistics showed that, for MBA students, problems within the ownership affect firm performance more often in family-owned firms than in non-family businesses. Likewise, MBAs believe that family-owned firms often have more difficulties in attracting good managers than non-family companies. Regarding the level of job rotation, MBA students think familyowned firms are better at keeping their employees within the firm as compared to non-family firms. In terms of international ventures, family-owned firms are seen as slower in their internationalization processes when compared to non-family businesses. Similarly, MBA students believe that family-owned companies tend to procrastinate more over the implementation of new technologies in contrast to their non-family firm counterparts. Referring to going public, MBA students perceive that family-owned firms have more difficulty in issuing equity to outside investors than do non-family companies. Moreover, MBAs think that the age of retirement in family-owned firms is often higher than in non-family organizations. Likewise, MBAs perceive family-owned businesses as more nepotistic than non-family businesses.

In order to study whether future family owners (next generation members) and non-family owners differ in their perceptions regarding family firms, the sample was split into two groups: future family owners and non-family owners (for future family owners see Tables 2.1-2.6 and for non-family owners see Tables 3.1-3.6 (Appendices B and C). To assess whether the means of the two groups are statistically different from each other, a $t$ test was conducted. The $t$ value showed significant differences between the two groups regarding the implementation of new technologies $(p<0.05)$, internationalization $(p<0.05)$, issue equity $(p<0.05)$, nepotism $(p<0.05)$, the quality of the board of directors $(p<0.10)$ and access to information $(p<0.10)$ (see Table 4, Appendix D). 
More specifically, in relation to the implementation of new technologies, future family owners are more likely to perceive that family-owned firms are slower than non-family businesses. Likewise, regarding internationalization, the future family owner group is more likely to appreciate that family-owned firms are slower than non-family companies. As for issue equity, non-family owners are more likely to perceive difficulties in selling equities to outsiders in family-owned firms, while future family owners perceive fewer difficulties for family firms to issue equity. Similarly, non-family owners perceive more nepotism in family-owned firms than do future family owners. Regarding the access to information, the non-family owner group is more likely to think that the access to information is worse in family-owned firms than the future family owner group. Finally, non-family owners perceive more often that the quality of the board of directors is worse in family-owned firms than do future family owners.

\section{Discussion}

Maximizing the acquisition of talent is vital for family-owned firms in today's highly competitive environment. In this sense, MBA graduates represent an important pool of talent that can help family-owned firms to thrive. Consequently, looking at the perceptions that MBA students hold about this type of organization is a paramount issue for family business research. Following this line of thought, the present study is among the first attempts to address such an important topic. The study has brought to the forefront interesting findings and opportunities to conduct further research, as well as information for enriching MBA courses on family business.

Looking at the results obtained from the perceptual data of the MBA students, we believe that they should be of interest to family-owned firms. Having an insight into the "perceptual map" of business administration graduates can be useful in the decisions of family-owned businesses to reassess the image they want to project to this particular important group of talented individuals, as well as to other labor markets. For example, following the results obtained, family-owned businesses could take a look at their conflict management strategies - how differences among family members are handled and resolved - since the best predictor of family business success is not the absence of conflict but its management. Even if conflicts are upsetting for family members at the time, they can be necessary and beneficial to a relationship in the long run. Conflict is not destructive to a relationship if it is handled and counterbalanced by positive emotions, particularly trust, affection, humor, positive problem solving, empathy and an active non-defensive listening style. Effective conflict management necessitates open disagreement with good communication skills. The building of good communication will empower the family to fight for their relationships and for their business project. Family firms must, therefore, have a global orientation to see the nature of their family business as comprehensible, manageable and meaningful. In this sense, relationship conflicts should be viewed as challenges that the family must be motivated to deal with successfully.

Likewise, considering the negative consequences that nepotism brings in its wake, familyowned firms must find a way to nip nepotism in the bud. This could be done by framing some anti-nepotism guidelines that may be included in the family protocol. First of all, the family firm should define job duties and make sure that everyone (family and non-family alike) is hired and rewarded based on their competence in accomplishing the business objectives. Family members often work in the family firm regardless of their educational background and experience, and they usually occupy positions higher than they would do in non-family firms. In these cases, the discussion regarding the strengths of each family member and how can they 
be efficiently applied to the firm is paramount. In contrast to gifted job positions, keeping highperformance expectation for family members and non-family members will make them develop their skills and use them to the utmost. Recent research on positive psychology has found that, when employees encounter challenging situations and use their skills to the utmost, they often experience what has been denominated as "flow." Empirical evidence shows that the experience of flow strongly influences an individual's subjective well-being.

Likewise, the process of internationalization appears to be a challenging endeavour for familyowned firms. Nevertheless, most organizations now have to think globally if they wish to thrive. Therefore, family-owned firms must be able to engage in international ventures when the need arises. In this sense, the fact that one or several family members may need to move to another country to lead a new business can be a setback for family-owned firms, in the sense that family communication and cohesion may be threatened. However, this restricting factor can be reduced by enhancing the "endowment" of international attitudes of the family; that is, the higher this international attribute, the more it will facilitate the process of internationalization. Obtaining these international capacities can be easier if the family members, especially the next generation members, are encouraged to learn other languages, to travel and to spend some time in other countries. The contact with different cultural environments may be an eye opener for the family-owned firm.

Similarly, adopting new information technologies seems to be a challenging step for familyowned firms. Nevertheless, they should try to train and modernize their workforce continuously. In this sense, family-owned firms must pay due attention to the continuous acquisition of new technology in order to be able to respond appropriately to changing environmental conditions. They should tackle this challenge by becoming flexible enough in their business strategy in a way that continues adding value to the business.

MBA students perceive that family-owned businesses are considerably worse in terms of attracting good managers to their top management teams. It is essential that family-owned firms appreciate this situation and seek the best way to attract talent to their managerial positions. To this end, it is vital to demonstrate that the influence of the family will be used to the benefit of the organization and its employees. Also, they must show their strong concern for the future of the firm, which can give managers a sense of security and assurance that they will be able to pursue long term professional goals within a stable business framework. Likewise, family-owned firms must bring out their positive qualities, such as the family values and principles, upon which the business strategy is built. These values and principles can become the very reason that makes family-owned firms rewarding and attractive places to work.

Moreover, family-owned businesses are perceived as having more difficulties for issuing equity compared to non-family firms. In this sense, family-owned businesses should be aware that it is still possible to manage the business in partnership with outside shareholders, who are willing to invest in the business. Nevertheless, it is important to emphasize that family-owned businesses often have a special closed shareholder system, which goes in line with their ultimate financial objective: to maximize the value of the company without losing control and ownership power. Moreover, the value of a share in family firms is not always purely economic but rather involves other motivations like the pride of belonging to the business, the emotional attachment to the company and passing the family legacy to future generations.

The age of retirement in family-owned firms is perceived by MBAs as being higher than in non-family organizations; this perception is in line with the family business literature. In this 
sense, family-owned firms must take into account that the existence of long CEO tenures, can result in an over-involvement of the CEO in the firm, which may cause conflict between generations, especially during the process of succession. This over-involvement is generally more pronounced in the case of a founder, given the great influence that founders have on the construction of the firm, and they are usually reluctant to leave their position. In successful multigenerational firms, when the time arrives for the CEO to leave, the incumbent and the successor share ideas regarding the future of the firm, offer feedback and encourage mutual learning. In this sense, the incorporation of the successor in the firm, following a structured procedure, as well as the preparation of the incumbent for his or her retirement is vital for maintaining harmony within the business, which in turn can make family-owned firms more attractive in the eyes of MBAs.

In our view, family-owned firms should consider overcoming this somewhat negative image that MBA students have about them, by emphasizing the advantages of working with them; such as the fact that family-owned firms often enjoy lower levels of job rotation and go beyond the material needs of employees (i.e., salary, fringe benefits) to fulfill other important needs, such as the cognitive and affective needs of employees. Ferreiro and Alcázar (2003), proposed a theoretical model of employee needs. They suggest three levels of needs: 1) within the first level, we find the material needs. Their fulfillment will derive in employee efficacy; 2) at the second level, we find the cognitive needs, which refer to employee training, feedback systems, psychological support, empowerment and job enrichment. The realization of these needs will lead to an increase on the attractiveness of the job; finally, 3) the third level represents the affective needs; justice, trust, self esteem, gratitude and personal development. The fulfillment of affective needs will result in group cohesion and mutual trust. From our point of view, family firms often pay more attention to the cognitive and affective needs than to the material ones. This can be explained through the emotional bond family members hold for the business, which in turn leads to an interest in the well-being and happiness of their employees. Following this line of thought, empirical evidence has found that material possessions present a surprisingly low correlation with happiness (Seligman, 2002). In other words, fringe benefits, promotions, and an increase in salary add little or nothing to a person's subjective well-being. Therefore, it can be hypothesized that family-owned businesses, which promote their workforce well-being, through the fulfillment of cognitive and affective needs, may outperform nonfamily companies that use material rewards as the main motivation for working.

In this sense, family-owned firms that are willing to attract MBA talent must promote their alluring strengths, such as their genuine interest in creating a positive work atmosphere which can aid employee retention. As has been discussed before, family-owned firms often shape their strategy around a set of family principles and values which emphasize continuity, integrity and trust among stakeholders. In this sense, the well-being of stakeholders has an intrinsic value and forms a moral foundation for their corporate strategy. We argue that a major reason for this unique attitude comes from the love, trust, and commitment of a group of family members who have decided to stay together maintaining a long-term view of the business - not just as a purely economic asset, but as a legacy that will create wealth for the family and society. In this sense, it is important that family-owned businesses pay due attention to promoting themselves as attractive employment opportunities.

Moreover, it is also vital to emphasize that the educational curriculum as a whole should offer MBA students more exposure to family-owned firms. From our sample, the great majority of MBA students $(\mathrm{N}=119)$, considered they had only a moderate knowledge regarding familyowned business. Therefore it would be useful to select certain family-owned firms as role 
models and prepare business cases as class material for MBA students; this should offer MBAs exposure to family-owned businesses. Likewise, it would be interesting to organize debates, in which directors of family-owned organizations can discuss the results of the present study with MBA students; this way MBAs will be able to compare and contrast their perceptions against the reality of family-owned firms. The more family-owned business cases are discussed, the more MBA students will be familiar with this type of organization and consequently their knowledge regarding family-owned firms will increase. In this sense, the results from the current study can guide the design of business cases and activities, emphasizing the different issues that were explored in the study. This can offer valuable opportunities to teach what a family-owned-business really is, and to correct the sometimes misleading perceptions that MBA students may have of family-owned businesses.

Another interesting finding lies within the perceptual differences between the next generation members (future family business owners) and non-family business owners. Future family business owners, in general, appear to have a more positive image of family-owned firms than non-family business owners. The differences in perception may be explained by the concept of emotional ownership. Emotional ownership has been described as the strong cognitive and emotional attachment that next generation members often have for their family-owned business (Nicholson and Bjornberg, 2008). When a member of the next generation has a strong feeling of emotional ownership towards the family business, he or she often feels a desire to maintain and protect the family business, and this may result in a more positive image of family firms. Moreover, the fact that future family business owners acquire knowledge about the family business from a very young age will likely lead them to have a different view of family firms as compared to nonfuture family business owners. Although this can be a good explanation for the differences in perceptions, further qualitative research is needed to shed more light on why these differences emerge and how they affect the occupational decisions of MBA students.

\section{Conclusions}

MBA students appear to have a less favorable view of family-owned firms than non-family organizations. In our view, the perceptions of MBA students should be considered by familyowned firms as challenges and opportunities for attracting and retaining talent. On the one hand, we can observe a series of challenges, depicted by the present study, which emphasize that family-owned businesses are perceived by MBAs to have more problems within the ownership, are more nepotistic, have more difficulties in attracting good managers, are slower in their internationalization ventures, are more reluctant to implement new technologies, have more difficulty in issuing equity and the age of retirement is generally higher than in nonfamily organizations. Some of these perceptions are in line with the family business literature; therefore, creating appropriate strategies to tackle these challenges is vital for family-owned businesses if they wish to attract the "best" employees and succeed in today's highly competitive environment.

The study also reported opportunities for attracting talent into family-owned firms. More specifically, when they think of family-owned businesses, MBA students see them as better at keeping their employees within the firm. Looking at the family business literature, it appears that family-owned organizations tend to have a genuine interest in the welfare of their employees and are therefore more caring for their workforce. Thus we argue that the greatest drivers of employee engagement and talent retention are intangible and mostly related to the way the organizations 
look after the welfare of their employees. In this sense, this positive characteristic should be capitalized on by family-owned firms in their efforts to attract talented employees.

\section{Study Limitations and Future Research}

This study opens the door to future possibilities for analyzing the perceptions that MBA students hold for family-owned businesses. Results from the present study clearly depict that MBA students view family-owned firms differently from non-family businesses. Therefore, this study may be opening a new window to build upon current research and go further in our understanding of how family-owned firms are perceived by highly qualified potential employees. Researchers in this area could, using qualitative enquiry, further study the differences between future family owners' and non-family owners' perceptions of family-owned firms.

One of the limitations of the current study is the cross-sectional nature of its data; thus more longitudinal studies should be conducted, including at least two points in time for the data collection. For example, it may be interesting to address the students' perceptions regarding family-owned firms when they start their MBA course and then again once they have graduated; this would show whether the knowledge they acquire during their course has an effect on their perceptions about family-owned firms. Moreover, future research should include more women in the sample, as the sample of the present study is largely composed of men; it may be interesting to see whether perceptions regarding family-owned firms are different for men and for women. Moreover, the results could be further generalized by studying the perceptions of MBA students from different business schools, using larger samples of students in different countries. Similarly, more qualitative research should be conducted on the topic.

Finally, it may be interesting and worthwhile to look more deeply into why family-owned firms appear to be more caring about their employees' well-being; this is important in the sense of how much an increase of employee well-being contributes to the competitive advantages of this type of business. Therefore, more research is needed looking at the factors affecting the prevalence of satisfied and happy employees in family-owned firms. 


\section{References}

Allouche, J. and B. Amann (1997), "Le retour triomphant du capitalisme familial," L'expansion: Management Review, Vol. 85, pp. 92-99.

Anderson, R. C. and D. M. Reeb (2003), "Founding-Family Ownership and firm performance: Evidence from the S\&P 500," Journal of Finance, Vol. 58, pp. 1.301-1.328.

Astrachan, J. and M. Carey (1994), "Family businesses in the United States economy," Paper presented to The Center for the Study of Taxation, Washington, DC.

Barney, J. (1991), "Firm resources and sustained competitive advantage," Journal of Management, Vol. 17, pp. 99-120.

Beehr, T. A., J. A. Drexler and S. Faulkner (1997), "Working in small family businesses: empirical comparisons to non-family businesses," Journal of Organizational Behavior, Vol. 18, pp. 297-312.

Berman, S. L., A. C. Wicks, S. Kotha and T. M. Jones (1999), "Does Stakeholder Orientation Matter? The Relationship Between Stakeholder Management Models and Firm Financial Performance," Academy of Management Journal, Vol. 42, pp. 488-506.

Bhatnagar, J. (2004), "New dimensions of strategic HRM: HRIS talent management and application of HR Six Sigma," In Padaki, R., N. M. Agrawal, C. Balaji and G. Mahapatra (eds.), Emerging Asia: An HR Agenda, Tata McGraw-Hill, New Delhi.

Bhatnagar, J. (2007), "Talent management strategy of employee engagement of Indian ITES employees: key to retention," Employee Relations, Vol. 29, pp. 640-663.

Bjornberg, A. and N. Nicholson (2007), "The family climate scales," Family Business Review, Vol. 20, pp. 229-246.

Blondel, C., N. Rowell and L. Van der Heyden (2001), "Prevalence of patrimonial firms in the SBF 250: Evolution from 1993 to 1998," Research paper, INSEAD.

Carrasco-Hernández, A. and G. Sánchez-Marín (2007), “The determinants of employee compensation in family firms: empirical evidence," Family Business Review, Vol. 20, pp. 215228.

Ceja, L. (2008), "Flow experiences and family business owners' entrepreneurs: A study using the experience sampling method,” Family Business Chair IESE, Work in progress.

Corbetta, G. and C. Salvato (2004), "Self-serving or self-actualizing? Models of man and agency costs in different types of family firms: A commentary on comparing the agency costs of family and nonfamily firms: Conceptual issues and exploratory evidence," Entrepreneurship Theory and Practice, Vol. 28, pp. 355-362.

Csikszentmihalyi, M. (1990), "Flow: The psychology of optimal experience," New York, Harper and Row.

Daily, C. M. and M. J. Dollinger (1992), "An empirical examination of ownership structure in family and professionally managed firms," Family Business Review, Vol. 5, pp. 117-136. 
Davis, P. S. and P. D. Harveston (2000), "Internationalization and organizational growth: The impact of Internet usage and technology involvement among entrepreneur-led family businesses," Family Business Review, Vol. 13, pp. 107-120.

DeMoss, M. (2001), "Destroying myths and creating value: The hollis experience in the publix family business," Paper presented at the Stetson University's Second Annual Family Business Gathering, Dedland, Florida: The Stetson University.

Demsetz, H. and K. Lehn (1985), “The structure of corporate ownership," Journal of Political Economy, Vol. 93, pp. 1155-1177.

Denison, D., C. Lief and J. Ward (2004), "Culture in family owned enterprises: Recognizing and leveraging unique strengths," Family Business Review, Vol. 17, pp. 61-70.

Diener, E. (2000), "Subjective well-being: The science of happiness and a proposal for a national index," American Psychologist, Vol. 55, pp. 34-43.

Dyer, W. G. (1986), "Cultural change in family firms: Anticipating and managing businesses and family transition," San Francisco, Jossey-Bass Publisher.

Dyer, W. G. (2003), "The Family: The Missing Variable in Organizational Research," Entrepreneurship Theory and Practice, Vol. 27, pp. 401-416.

Dyer, W. G. (2003), "The Family: The Missing Variable in Organizational Research," Entrepreneurship Theory and Practice, Vol. 2, pp. 401-416.

Eddleston, K. A. and F. W. Kellermanns (2007), "Destructive and productive family relationships: A stewardship theory perspective," Journal of Business Venturing, Vol. 22, pp. 545-565.

Einarsen, S., H. Hoel, D. Zapf and C. L. Cooper (2003.), "Bullying and emotional abuse in the workplace, International perspectives in research and practice," London and New York, Taylor and Francis.

Feltham, T. S., G. Feltham and J. J. Barnett (2005), "The Dependence of Family Businesses on a Single Decision-Maker,” Journal of Small Business Management, 43, pp. 1-15.

Fernández, M. and J. Tàpies (2008), “Age and size in family-owned businesses in Spain,” IESE Family Business Chair (work in progress).

Ferreiro, P. and M. Alcázar (2003), “Gobierno de personas en la empresa,” Editorial: Universidad de Piura.

Fiegener, M. K., B. M. Brown, R. A. Prince and K. M. File (1996), "Passing on Strategic Vision. Favoured Modes of Successor Preparation by CEOs of Family and Nonfamily Firms," Journal of Small Business Management, Vol. 34, pp. 15-26.

Gallo, M. A. and M. J. Estapé (1992), “Internationalization of the family business," Research paper no. 230, IESE Business School.

Gallo, M. A. and C. García Pont (1996), "Important factors in the internationalization of familyowned businesses,” Research paper No. 256, IESE Business School. 
Gallo, M. A. and J. Sveen (1999), "Internationalizing the family business: Facilitating and retraining factors," Family Business Review, Vol. 4, No. 2, pp. 181-190.

Gallo, M. A., A. Ariño, I. Máñez and K. Cappuyns (2004), "Internationalization via strategic alliances in family businesses," Working paper family business chair IESE Business School.

Gallo, M. A., J. Tàpies and K. Cappuyns (2004), “Comparison of family and nonfamily business: Financial logic and personal preferences,” Family Business Review, Vol. 17, pp. 303-318.

Gersick, K. E., J. A. Davis, M. M. Hamptom and I. Lansberg (1997), “Generation to Generation: Life Cycles of the family business," Harvard Business School Press.

Gómez-Mejía L. R., M. Makri and M. Larraza (2008), "Diversification decisions in familycontrolled firms," Working paper.

Gómez-Mejía, L. R., K. Haynes, M. Nunez-Nickel, K. Jacobson and J. Moyano-Fuentes (2007), "Socioemotional wealth and Business risks in family controlled firms: evidence from Spanish olive oil Mills," Administrative Science Quarterly, Vol. 52, pp. 106-137.

Gómez-Mejía, L. R., M. Nuñez-Nickel and I. Gutiérrez (2001), "The role of family ties in agency contracts," Academy of Management Journal, Vol. 44, pp. 81-95.

Graves, C. and J. Thomas (2004), "Internationalization of the family business: A longitudinal perspective," International Journal of Globalisation and Small Business, Vol. 1, pp. 7-27.

Guzzo, R. and S. Abbott (1990), "Family firms as utopian organizations," Family Business Review, Vol. 3, pp. 23-33.

Harvey, M. and R. E. Evans (1994), "Family Business and multiple levels of conflict," Family Business Review, Vol. 7, pp. 331-348.

Hirigoyen, G. and T. Poulain-Rehm (2000), "La politique de stock-options des enterprises familiales cotées: quelques résultats empiriques," Finance, Contrôle, Stratégie, Vol. 3, pp. 139-167.

Howorth, C., P. Westhead and M. Wright (2004), "Buyouts, information asymmetry and the family management dyad," Journal of Business Venturing, Vol. 19, pp. 509-534.

James, H. S. (1999), “Owner as manager, extended horizons and the family firm," International Journal of the Economics of Business, Vol. 6, pp. 41-55.

Jensen, M. C. and W. H. Meckling (1976), "Theory of the firm: Managerial Behavior, Agency costs and ownership structure,” Journal of financial economics, Vol. 3, pp. 303-360.

Johnson, C. and R. Ford (2000), "Emotional reactions to conflict: Do dependence and legitimacy matter?” Social Forces, Vol. 79, pp. 107-138.

Kets de Vries, M. F. R (1985), "The Dark Side of Entrepreneurship," Harvard Business Review, Nov./Dec., Vol. 63, pp. 160-167.

Kets de Vries, M. F. R. (1993), "The dynamics of family controlled firms: the good and the bad news," Organization Dynamics, Vol. 21, pp. 303-324.

Khurana, R. (2003), “Searching for corporate savior,” Princeton, NJ, Princeton University Press. 
Kleiman, R., W. Petty and J. Martin (1995), "Family controlled firms: An assessment of performance," Proceedings of the Second Annual Conference of the International Family Business Program Association, Nashville, TN, July.

Klein, S. B. and F. A. Bell (2007), "Non-family executives in family businesses - A literature review,” Electronic Journal of Family Business Studies, Vol. 1, pp. 19-37.

Lansberg, I. (1983), "Managing Human Resources in Family Firms: The Problem of Institutional Overlap,” Organizational Dynamics, summer, pp. 39-46.

Lansberg, I. (1999), “Succeeding Generations,” Harvard Business School Press.

Le Breton-Miller, I. and D. Miller (2006), "Why do some Family Businesses Out-Compete? Governance, Long-Term Orientations, and Sustainable Capability," Entrepreneurship, Theory and Practice, Vol. 30, pp. 731-746.

Lee, J. (2006), "Family firm performance: Further evidence," Family Business Review, Vol. 19, pp. 103-114.

Lowery, C. M., M. M. Petty and J. W. Thompson (2008), "Assessing the merit of merit pay: employee reactions to performance-based pay," Human Resource Planning.

McKinsey (2004), “Survey of 7,300 executives,” February.

Michael-Tsabari, N., Y. Lavee and S. Hareli (2008), "Stereotypes of Family Businesses and their role in Choosing a Workplace," Paper presented at the $8^{\text {th }}$ International Family Enterprise Research Academy (IFERA) Conference, Nyenrode, The Netherlands.

Miller, D. and I. Le Breton-Miller (2003), "Challenge versus advantage in family businesses," Strategic Organization, Vol. 1, pp.127-134.

Miller, D. and I. Le Breton-Miller (2005), "Managing for the long run,” Boston: Harvard Busines School Press.

Miller, D., I. Le Breton-Miller and B. Scholnick (2008), "Stewardship vs. Stagnation: An Empirical Comparison of Small Family and Non-Family Businesses," Journal of Management Studies, Vol. 45, pp. 51-78.

Mishra, C. S. and D. L. McConaughy (1999), "Founding family control and capital structure: The risk of loss of control and the aversion to debt", Entrepreneurship Theory and Practice, Vol. 23, pp. 53-64.

Nicholson, N. and A. Bjornberg (2008), "The shape of things to come- Emotional Ownership and the next generation in the family firm," In Tàpies, J. and J. Ward (eds.), "Family Values and Value Creation," Palgrave MacMillan.

Ogbonna, E. and C. L. Harris (2005), "The adoption and use of information technology: a longitudinal study of a mature family firm," New Technologies, Work and Employment, Vol. 20, pp. 1-18.

Padgett, M. Y. and K. A. Morris (2005), "Keeping it! All in the family: Does Nepotism in the Hiring Process Really Benefit the Beneficiary?," Journal of Leadership and Organizational Studies, Vol. 11, pp. 34-45. 
Pagano, Marco, Fabio Panetta and Luigi Zingales (1998), "Why Do Companies Go Public? An Empirical Analysis," Journal of Finance, Vol. 1, pp. 27-64.

Poutziouris, P. (2001), "The views of family companies on venture capital: Empirical evidence from the UK small to medium-size enterprising economy," Family Business Review, Vol. 14, pp. 277-291.

Poza, E. J. (1995), “A la sombra del roble: La empresa familiar y su continuidad,” Cleveland, OH, Editorial Universitaria para la Empresa Familiar.

Ronn, K. (2007), “Rethinking talent acquisition,” Business Week Online, No. 3 June.

Saito, T. (2008), "Family firms and firm performance: evidence from Japan," Journal of Japanese International Economics, Vol. 22, pp. 620-646.

Schulze, W. S., M. H. Lubatkin and R. N. Dino (2003), "Toward a theory of agency and trust in family firms," Journal of Business Venturing, Vol. 18, pp. 473-490.

Seligman, M. E. P. (2002), “Authentic Happiness,” The Free Press, New York

Simon, H. (1996), "Hidden champions: lessons from 500 of the world's best unknown companies," Boston, Harvard Business School Press.

Sorenson, R. L. (1999), "Conflict management strategies used in successful family businesses," Family Business Review, Vol. 12, pp. 325-339.

Stavrou, E., G. Kassinis and A. Filotheou (2006), "Downsizing and Stakeholder Orientation Among The Fortune 500: Does Family Ownership Matter?," Academy of Management Best Conference Paper 2006.

Stein, J. (1989), "Efficient capital markets, inefficient forms: A model of myopic corporate behaviour," Quarterly Journal of Economics, Vol. 103, pp. 655-669.

Tagiuri, R. and J. Davis (1996), "Bivalent Attributes of the family firm," Family Business Review, Vol. 9, pp. 199-208.

Tàpies, J. and L. Reinoso (2005), "Las empresas familiares y la bolsa española, Mitos y realidades," In "Empresas familiares y bolsa” (pp. 53-71), Fundación de Estudios Bursátiles y Financieros, Navarra, Editorial Aranzadi, S.A.

Taylor, M. S. and C. J. Collins (2000), "Organizational recruitment: enhancing the intersection of theory and practice," In Cooper, C. L. and E. A. Locke, (eds.), "Industrial and Organizational Psychology: Linking Theory and Practice," Basil Blackwell, Oxford, pp. 304-334.

Thomsen, S. and T. Pedersen (2000), "Ownership structure and economic performance in the largest European companies," Strategic Management Journal, Vol. 21, pp. 689-705.

Villalonga B. and R. Amit (2006), "How Do Family Ownership, Control, and Management Affect Firm Value,” Journal of Financial Economics, Vol. 80, pp. 385-417.

Ward, J. L. (1987), "Keeping the Family Business Healthy: How to Plan for Continuing Growth, Profitability, and Family Leadership,” Jossey-Bass, San Francisco.

Ward, J. L. (1991), "Perpetuating the family business," Family Business Sourcebook, Omnigraphics, Detroit. 
Ward, J. L. (2004), "Perpetuating the family business." Marietta, GA, Family Enterprise Publishers.

Werner, S., H. Tosi and L. R. Gómez-Mejía (2005), "Organizational governance and employee pay: How ownership structure affects the firm's compensation strategy," Strategic Management Journal, Vol. 26, pp. 377-384.

Westhead, P., M. Cowling and C. Howorth (2001), "The development of family companies: management and ownership issues," Family Business Review, Vol. 14, pp. 369-385.

Zapf, D., S. Einarsen, H. Hoel and M. Vartia (2003), "Empirical findings on bullying in the workplace," In Einarsen, S., H. Hoel, D. Zapf and C. L. Cooper (eds.), "Bullying and emotional abuse in the workplace, International perspectives in research and practice," (pp. 103-126), London and New York: Taylor and Francis. 


\section{Appendices}

\section{Appendix A}

\section{Descriptive statistics}

\section{Table 1.1}

Implementation of strategic changes

\section{Family Firms Versus Non-family Firms}

Frequencies

\begin{tabular}{lrrrrrr}
\hline & Much slower & Slower & Equal & Faster & Much faster & Not sure \\
Use of new technologies & $11.7 \%$ & $\mathbf{5 1 . 2} \%$ & $18.3 \%$ & $13.1 \%$ & $1.4 \%$ & $4.2 \%$ \\
Diversification & $4.7 \%$ & $\mathbf{4 4 . 6 \%}$ & $21.6 \%$ & $20.2 \%$ & $4.7 \%$ & $3.8 \%$ \\
Internationalization & $17.4 \%$ & $\mathbf{5 7 . 7} \%$ & $10.8 \%$ & $8.0 \%$ & $1.9 \%$ & $3.8 \%$ \\
Building strategic alliances & $9.9 \%$ & $\mathbf{3 9 . 0 \%}$ & $17.8 \%$ & $19.2 \%$ & $8.5 \%$ & $5.2 \%$ \\
\hline
\end{tabular}

\section{Table 1.2}

Financial performance

\section{Family Firms Versus Non-family Firms}

Frequencies

\begin{tabular}{rrrrrr}
\hline & Much worse & Worse & Equal & Better & Much better \\
Financial performance & $5 \%$ & $23.9 \%$ & $35.7 \%$ & $\mathbf{3 7 . 1} \%$ & $1.9 \%$ \\
\hline
\end{tabular}

\section{Table 1.3}

Talent management in family firms

\section{Family Firms Versus Non-family Firms}

Frequencies

\begin{tabular}{|c|c|c|c|c|c|}
\hline & Much worse & Worse & Equal & Better & Much better \\
\hline Skills of the management team & $2.8 \%$ & $36.6 \%$ & $44.6 \%$ & $14.6 \%$ & $9.0 \%$ \\
\hline Capacity to attract good managers & $10.3 \%$ & $68.1 \%$ & $15.0 \%$ & $4.7 \%$ & $0.9 \%$ \\
\hline Salary & $0.9 \%$ & $37.0 \%$ & $36.2 \%$ & $25.0 \%$ & $0.5 \%$ \\
\hline Fringe benefits & $1.9 \%$ & $35.0 \%$ & $33.0 \%$ & $23.5 \%$ & $4.2 \%$ \\
\hline Access to information & $8.0 \%$ & $43.2 \%$ & $20.2 \%$ & $21.6 \%$ & $6.1 \%$ \\
\hline Stock options & $21.1 \%$ & $47.4 \%$ & $14.1 \%$ & $13.1 \%$ & $1.9 \%$ \\
\hline Freedom over decisions & $8.9 \%$ & $39.9 \%$ & $16.9 \%$ & $24.9 \%$ & $8.0 \%$ \\
\hline Selection and training of successors & $8.9 \%$ & $43.7 \%$ & $14.6 \%$ & $28.2 \%$ & $3.3 \%$ \\
\hline Quality of the board of directors & $7.5 \%$ & $38.5 \%$ & $42.3 \%$ & $8.9 \%$ & $1.9 \%$ \\
\hline Representation of the owners' interests & $1.4 \%$ & $4.2 \%$ & $13.6 \%$ & $43.7 \%$ & $35.7 \%$ \\
\hline
\end{tabular}




\section{Appendix A (continued)}

\section{Table 1.4}

Financial difficulties for growing

\begin{tabular}{|c|c|c|c|c|c|}
\hline \multicolumn{6}{|c|}{ Frequencies } \\
\hline & Much lower & Lower & Equal & Higher & Much higher \\
\hline Difficulties obtaining loans & $1.4 \%$ & $16.8 \%$ & $44.1 \%$ & $34.3 \%$ & $1.9 \%$ \\
\hline Difficulties issuing equity & $4.2 \%$ & $9.4 \%$ & $25.4 \%$ & $51.2 \%$ & $8.0 \%$ \\
\hline $\begin{array}{l}\text { Difficulties including/accepting new } \\
\text { shareholders }\end{array}$ & $8.0 \%$ & $7.0 \%$ & $11.3 \%$ & $47.0 \%$ & $25.4 \%$ \\
\hline $\begin{array}{l}\text { Difficulties retaining earnings due to } \\
\text { dividend policy }\end{array}$ & $9.4 \%$ & $31.5 \%$ & $25.4 \%$ & $29.0 \%$ & $2.3 \%$ \\
\hline
\end{tabular}

\section{Table 1.5}

Management of people in family firms

Family Firms Versus Non-family Firms

Frequencies

\begin{tabular}{lrrrrr}
\hline & Much lower & Lower & Equal & Higher & Much higher \\
Job rotation & $11.0 \%$ & $\mathbf{6 0 . 1} \%$ & $14.6 \%$ & $11.7 \%$ & $10.8 \%$ \\
Age of retirement & $2.3 \%$ & $7.0 \%$ & $25.4 \%$ & $\mathbf{4 9 . 8} \%$ & $15.0 \%$ \\
Nepotism & $0.5 \%$ & $6.1 \%$ & $30.0 \%$ & $\mathbf{4 1 . 8 \%}$ & $19.2 \%$ \\
\hline
\end{tabular}

\section{Table 1.6}

Personal problems within the ownership

\section{Family Firms Versus Non-family Firms}

Frequencies

\begin{tabular}{rrrr}
\hline & Much frequently & Equal & Less frequently \\
Personal problems within the ownership & $\mathbf{8 3 . 1 \%}$ & $15.0 \%$ & $1.4 \%$ \\
\hline
\end{tabular}




\section{Appendix B}

Descriptive statistics: perceptions of future family owners

Table 2.1

Implementation of strategic changes

\section{Family Firms Versus Non-family Firms}

\begin{tabular}{|c|c|c|c|c|c|c|}
\hline \multicolumn{7}{|c|}{ Frequencies } \\
\hline & Much slower & Slower & Equal & Faster & Much faster & Not sure \\
\hline Use of new technologies & $15.1 \%$ & $60.5 \%$ & $9.3 \%$ & $14.0 \%$ & $0 \%$ & $1.2 \%$ \\
\hline Diversification & $5.8 \%$ & $45.3 \%$ & $23.3 \%$ & $20.9 \%$ & $4.7 \%$ & $0 \%$ \\
\hline Internationalization & $23.3 \%$ & $57.0 \%$ & $9.3 \%$ & $8.1 \%$ & $1.2 \%$ & $1.2 \%$ \\
\hline Building strategic alliances & $12.8 \%$ & $37.2 \%$ & $19.8 \%$ & $18.6 \%$ & $9.3 \%$ & $2.3 \%$ \\
\hline
\end{tabular}

\section{Table 2.2}

Financial performance

\section{Family Firms Versus Non-family Firms}

Frequencies

\begin{tabular}{lrrrrr}
\hline & Much worse & Worse & Equal & Better & Much better \\
Financial performance & $0 \%$ & $25.6 \%$ & $30.2 \%$ & $\mathbf{4 0 . 7 \%}$ & $2.3 \%$ \\
\hline
\end{tabular}

\section{Table 2.3}

Talent management in family firms

\section{Family Firms Versus Non-family Firms}

Frequencies

Skills of the management team Capacity to attract good managers

\section{Salary}

Fringe benefits

Access to information

Stock options

Freedom over decisions

Selection and training of successors

Quality of the board of directors

Representation of the owners' interests

\begin{tabular}{rrrrr} 
Much worse & Worse & Equal & Better & Much better \\
$3.5 \%$ & $29.1 \%$ & $\mathbf{5 2 . 3} \%$ & $14.0 \%$ & $1.2 \%$ \\
$10.5 \%$ & $\mathbf{7 0 . 9 \%}$ & $10.5 \%$ & $5.8 \%$ & $2.3 \%$ \\
$0 \%$ & $\mathbf{3 9 . 5 \%}$ & $33.7 \%$ & $25.6 \%$ & $1.2 \%$ \\
$2.3 \%$ & $\mathbf{3 3 . 7 \%}$ & $27.9 \%$ & $24.4 \%$ & $9.3 \%$ \\
$3.5 \%$ & $\mathbf{4 0 . 7 \%}$ & $23.3 \%$ & $26.7 \%$ & $5.8 \%$ \\
$25.6 \%$ & $\mathbf{4 7 . 7 \%}$ & $14.0 \%$ & $8.1 \%$ & $2.3 \%$ \\
$4.7 \%$ & $\mathbf{4 6 . 5 \%}$ & $11.6 \%$ & $26.7 \%$ & $9.3 \%$ \\
$7.0 \%$ & $\mathbf{5 2 . 3} \%$ & $11.6 \%$ & $24.4 \%$ & $3.5 \%$ \\
$3.5 \%$ & $38.4 \%$ & $\mathbf{4 3 . 0} \%$ & $12.8 \%$ & $2.3 \%$ \\
$1.2 \%$ & $7.0 \%$ & $10.5 \%$ & $\mathbf{4 1 . 9} \%$ & $39.5 \%$ \\
& & & & \\
\hline
\end{tabular}




\section{Appendix B (continued)}

\section{Table 2.4}

Financial difficulties for growing

\begin{tabular}{|c|c|c|c|c|c|}
\hline \multicolumn{6}{|c|}{ Frequencies } \\
\hline & Much lower & Lower & Equal & Higher & Much higher \\
\hline Difficulties obtaining loans & $1.2 \%$ & $15.1 \%$ & $53.5 \%$ & $26.7 \%$ & $2.3 \%$ \\
\hline Difficulties issuing equity & $8.1 \%$ & $11.6 \%$ & $25.6 \%$ & $44.2 \%$ & $8.1 \%$ \\
\hline $\begin{array}{l}\text { Difficulties including/accepting new } \\
\text { shareholders }\end{array}$ & $12.8 \%$ & $5.8 \%$ & $9.3 \%$ & $40.7 \%$ & $30.2 \%$ \\
\hline $\begin{array}{l}\text { Difficulties retaining earnings due to } \\
\text { dividend policy }\end{array}$ & $10.5 \%$ & $32.6 \%$ & $23.3 \%$ & $26.7 \%$ & $2.3 \%$ \\
\hline
\end{tabular}

\section{Table 2.5}

Management of people in family firms

Family Firms Versus Non-family Firms

Frequencies

\begin{tabular}{lrrrrr}
\hline & Much lower & lower & Equal & Higher & Much higher \\
Job rotation & $17.4 \%$ & $\mathbf{5 7 . 0 \%}$ & $11.6 \%$ & $11.6 \%$ & $2.3 \%$ \\
Age of retirement & $4.7 \%$ & $7.0 \%$ & $24.4 \%$ & $\mathbf{4 5 . 3} \%$ & $18.6 \%$ \\
Nepotism & $1.2 \%$ & $8.1 \%$ & $36.0 \%$ & $\mathbf{3 7 . 2} \%$ & $16.3 \%$ \\
\hline
\end{tabular}

\section{Table 2.6}

Personal problems within the ownership

\section{Family Firms Versus Non-family Firms}

Frequencies

\begin{tabular}{rrrr}
\hline & Much frequently & Equal & Less frequently \\
Personal problems within the ownership & $\mathbf{8 6 . 0 \%}$ & $11.6 \%$ & $2.3 \%$ \\
\hline
\end{tabular}




\section{Appendix C}

Descriptive statistics: perceptions of non-family owners

\section{Table 3.1}

Implementation of strategic changes

\section{Family Firms Versus Non-family Firms}

\begin{tabular}{|c|c|c|c|c|c|c|}
\hline \multicolumn{7}{|c|}{ Frequencies } \\
\hline & Much slower & Slower & Equal & Faster & Much faster & Not sure \\
\hline Use of new technologies & $9.5 \%$ & $44.4 \%$ & $24.6 \%$ & $12.7 \%$ & $2.4 \%$ & $6.3 \%$ \\
\hline Diversification & $4.0 \%$ & $43.7 \%$ & $20.6 \%$ & $19.8 \%$ & $4.8 \%$ & $6.3 \%$ \\
\hline Internationalization & $13.5 \%$ & $58.7 \%$ & $11.1 \%$ & $7.9 \%$ & $2.4 \%$ & $5.6 \%$ \\
\hline Building strategic alliances & $7.9 \%$ & $40.5 \%$ & $15.9 \%$ & $19.8 \%$ & $7.9 \%$ & $7.1 \%$ \\
\hline
\end{tabular}

\section{Table 3.2}

Financial performance

\section{Family Firms Versus Non-family Firms}

Frequencies

\begin{tabular}{rrrrrr}
\hline & Much worse & Worse & Equal & Better & Much better \\
Financial performance & $0.8 \%$ & $23.0 \%$ & $39.7 \%$ & $34.1 \%$ & $1.6 \%$ \\
\hline
\end{tabular}

\section{Table 3.3}

Talent management in family firms

\section{Family Firms Versus Non-family Firms}

Frequencies

Skills of the management team

Capacity to attract good managers

Salary

Fringe benefits

Access to information

Stock options

Freedom over decisions

Selection and training of successors

Quality of the board of directors

Representation of the owners' interests

\begin{tabular}{rrrrr} 
Much worse & Worse & Equal & Better & Much better \\
$2.4 \%$ & $\mathbf{4 2 . 1 \%}$ & $39.7 \%$ & $15.1 \%$ & $0.8 \%$ \\
$10.3 \%$ & $\mathbf{6 6 . 7 \%}$ & $18.3 \%$ & $4.0 \%$ & $0 \%$ \\
$1.6 \%$ & $34.9 \%$ & $\mathbf{3 8 . 1} \%$ & $24.6 \%$ & $0 \%$ \\
$1.6 \%$ & $34.1 \%$ & $\mathbf{3 8 . 9} \%$ & $23.0 \%$ & $0.8 \%$ \\
$11.1 \%$ & $\mathbf{4 5 . 2 \%}$ & $18.3 \%$ & $18.3 \%$ & $6.3 \%$ \\
$18.3 \%$ & $\mathbf{4 7 . 6 \%}$ & $14.3 \%$ & $16.7 \%$ & $1.6 \%$ \\
$11.9 \%$ & $\mathbf{3 5 . 7 \%}$ & $20.6 \%$ & $23.8 \%$ & $7.1 \%$ \\
$10.3 \%$ & $\mathbf{3 8 . 1} \%$ & $16.7 \%$ & $31.0 \%$ & $3.2 \%$ \\
$10.3 \%$ & $38.9 \%$ & $\mathbf{4 2 . 1} \%$ & $6.3 \%$ & $1.6 \%$ \\
$1.6 \%$ & $2.4 \%$ & $15.9 \%$ & $\mathbf{4 5 . 2} \%$ & $33.3 \%$ \\
\hline
\end{tabular}




\section{Appendix C (continued)}

\section{Table 3.4}

Financial difficulties for growing

\begin{tabular}{|c|c|c|c|c|c|}
\hline \multicolumn{6}{|c|}{ Frequencies } \\
\hline & Much lower & Lower & Equal & Higher & Much higher \\
\hline Difficulties obtaining loans & $1.6 \%$ & $18.3 \%$ & $38.1 \%$ & $39.7 \%$ & $1.6 \%$ \\
\hline Difficulties issuing equity & $1.6 \%$ & $7.9 \%$ & $25.4 \%$ & $56.3 \%$ & $7.9 \%$ \\
\hline $\begin{array}{l}\text { Difficulties including/accepting new } \\
\text { shareholders }\end{array}$ & $4.8 \%$ & $7.9 \%$ & $12.7 \%$ & $51.6 \%$ & $22.2 \%$ \\
\hline $\begin{array}{l}\text { Difficulties retaining earnings due to } \\
\text { dividend policy }\end{array}$ & $8.7 \%$ & $31.0 \%$ & $27.0 \%$ & $30.0 \%$ & $2.4 \%$ \\
\hline
\end{tabular}

\section{Table 3.5}

Management of people in family firms

Family Firms Versus Non-family Firms

Frequencies

\begin{tabular}{lrrrrr}
\hline & Much lower & Lower & Equal & Higher & Much higher \\
Job rotation & $6.3 \%$ & $\mathbf{6 2 . 7 \%}$ & $16.7 \%$ & $11.9 \%$ & $2.4 \%$ \\
Age of retirement & $0.8 \%$ & $7.1 \%$ & $26.2 \%$ & $\mathbf{5 3 . 2} \%$ & $12.7 \%$ \\
Nepotism & $0 \%$ & $4.8 \%$ & $26.2 \%$ & $\mathbf{4 5 . 2} \%$ & $21.4 \%$ \\
\hline
\end{tabular}

\section{Table 3.6}

Personal problems within the ownership

\section{Family Firms Versus Non-family Firms}

\section{Frequencies}

\begin{tabular}{lrrr}
\hline & Much frequently & Equal & Less frequently \\
Personal problems within the ownership & $\mathbf{8 1 . 4 \%}$ & $17.5 \%$ & $0.8 \%$ \\
\hline
\end{tabular}




\section{Appendix D}

\section{Mean comparison}

\section{Table 4}

Comparative perceptions of family firms compared to non-family businesses: Future family-owners versus non-family-owners.

\begin{tabular}{lcc}
\hline & $t$ value & Significance \\
\hline Business issues & & \\
\hline Use of new technologies & -3.041 & $0.003^{\star *}$ \\
Diversification & -1.504 & 0.134 \\
Internationalization & -2.159 & $0.032^{\star *}$ \\
Strategic alliances & -1.048 & 0.296 \\
Financial performance & 0.610 & 0.542 \\
Skills of the management team & 0.963 & 0.337 \\
Capacity to attract good managers & 0.252 & 0.801 \\
Salary & 0.171 & 0.864 \\
Fringe benefits & 1.308 & 0.139 \\
Access to information & 1.856 & $0.065^{\star}$ \\
Stock options & -1.622 & 0.106 \\
Freedom over decisions & 0.682 & 0.496 \\
Selection and training of successors & -0.914 & 0.362 \\
Quality of the board of directors & 1.948 & $0.053^{\star}$ \\
Representation of Owners' interests & 0.280 & 0.780 \\
Difficulties obtaining loans & -0.687 & 0.493 \\
Difficulties issuing equity & -2.059 & $0.041^{* *}$ \\
Difficulties including/accepting new shareholders & -0.506 & 0.614 \\
Difficulties retaining earnings due to dividend policy & -0.644 & 0.520 \\
Job rotation & -1.306 & 0.193 \\
Age of retirement & -0.272 & 0.786 \\
Nepotism & -2.071 & $0.040^{\star *}$ \\
Personal problems within the ownership & -1.059 & 0.291 \\
\hline
\end{tabular}

** Significant at 5\% level.

* Significant at 10\% level. 


\section{Appendix E}

\section{Questionnaire items}

1. How fast do family firms implement strategic changes compared with non-family businesses, related to:

- The use of new technologies

- Diversification

- Internationalization

- Building strategic alliances
a) Much slower
b) Slower
c) Equal to NFB
d) Faster
e) Much faster
f) Not sure

2. When compared to non-family businesses the financial performance of family firms is generally:
a) Much worse
b) Worse
c) Equal
d) Better
e) Much better

3. How good is the talent management in family firms when compared to non-family businesses:

- The skills of the management team are:

- The capacity to attract good managers is:

- The salary is:

- The fringe benefits are:

- The access to information is:

- Given stock options are:

- The freedom over decisions is:

- The selection and training of successors is:

- The quality of board of directors is:

- The representation of the owners' interests is:
a) Much worse
b) Worse
c) Equal
d) Better
e) Much better 


\section{Appendix E (continued)}

4. Financial difficulties for growing: Family firms versus non-family firms

- Difficulties obtaining loans

- Difficulties issuing equity

- Difficulties including/accepting new shareholders

- Difficulties retaining earnings due to dividend policy
a) Much lower
b) Lower
c) Equal
d) Higher
e) Much higher

5. Managing people in family firms versus non-family firms

- Job rotation

- Age of retirement

- Nepotism
a) Much lower
b) Lower
c) Equal
d) Higher
e) Much higher

6. Personal problems within the ownership can affect the company's performance: Family firms versus non-family firms
a) More frequently
b) Equal
c) Less frequently 